\title{
THE EFFECTIVENESS OF GUIDED DISCOVERY LEARNING TO TEACH INTEGRAL CALCULUS FOR THE MATHEMATICS STUDENTS OF MATHEMATICS EDUCATION WIDYA DHARMA UNIVERSITY
}

\author{
Yuliana $^{1}$ Tasari $^{2}$, Septiana Wijayanti ${ }^{3}$ \\ ${ }^{1,2,3}$ Department of Mathematics Education Widya Dharma University, Klaten, Indonesia \\ 12pakyulikids@unwidha.ac.id, ${ }^{2}$ tasarilutfi@gmail.com, ${ }^{3}$ septiana.wijaya@ unwidha.ac.id
}

Received: October 7, 2016; Accepted: November 8, 2016

\begin{abstract}
The objectives of this research are (1) to develop Guided Discovery Learning in integral calculus subject; (2) to identify the effectiveness of Guided Discovery Learning in improving the students' understanding toward integral calculus subject. This research was quasy experimental research with the students of even semester in Mathematics Education Widya Dharma University as the sample. Cluster Random sampling was conducted to determine control group that was taught using Conventional model and experimental group that was taught using Guided Discovery Learning model. The instruments of this research included pre-test, post-test, and student's response questionnaire. The data of post-test was analyzed using T-test. The result was $\mathrm{H}_{0}$ was rejected for the level of significance $\alpha=5 \%$. The result of this data analysis found out that Guide Discovery Learning was more effective than Conventional Model. It was supported by the result questionnaire. The result of questionnaire that more than $75 \%$ questionnaire items got $67.65 \%$ positive response. It means Guided Discovery Learning can increase students' interest in joining integral calculus class.
\end{abstract}

Keywords: Guided Discovery Learning Model, Understanding toward Integral Calculus Concept

\begin{abstract}
Abstrak
Penelitian ini bertujuan untuk (1) mengembangkan model pembelajaran penemuan terbimbing pada materi kuliah kalkulus integral dan (2) mengetahui efektivitas model pembelajaran penemuan terbimbing dalam meningkatkan kemampuan pemahaman mahasiswa. Penelitian ini berbentuk eksperimen semu dengan sampel mahasiswa semester genap Program Studi Pendidikan matematika Universitas Widya Dharma Klaten. Sampel penelitian diambil secara cluster random sampling diperoleh satu kelas kontrol dengan perlakuan konvensional dan satu kelas eksperimen dengan perlakuan model penemuan terbimbing. Instrumen pada penelitian ini meliputi tes kemampuan awal (pre-test), tes kemampuan akhir (post-test), dan angket respon mahasiswa. Data post-test dianalisis menggunakan uji $\mathrm{t}$ dengan hasil menolak $\mathrm{H}_{0}$ untuk taraf signifikasi $\alpha=5 \%$. Hal ini memberikan kesimpulan bahwa rata-rata hasil post-test pada kelompok dengan model penemuan terbimbing lebih baik daripada kelompok dengan model konvensional sehingga dapat disimpulkan model penemuan terbimbing lebih efektif daripada model konvensional. Disamping itu, butir angket sekurangkurangnya $75 \%$ mendapat respon positif dari mahasiswa sebesar $67.75 \%$. Hal ini menunjukkan pembelajaran penemuan terbimbing mendapatkan respon positif.
\end{abstract}

Kata Kunci: model pembelajaran penemuan terbimbing, pemahaman konsep kalkulus integral

How to Cite: Yuliana, Tasari \& Wijayanti, S. (2017). The Effectiveness of Guided Discovery Learning to Teach Integral Calculus for the Mathematics Students of Mathematics Education Widya Dharma University. Infinity, 6 (1), 1-10. 


\section{INTRODUCTION}

The Introduction presents the purpose of the studies reported and their relationship to earlier work in the field. It should not be an extensive review of the literature. Use only those references required to provide the most salient background to allow the readers to understand and evaluate the purpose and results of the present study without referring to previous publications on the topic.

Integral is one of compulsory subject that must be learnt in even semester at Widya Dharma University in Klaten. The material is included in integral calculus subject. The understanding of integral calculus concept is highly needed for other subjects in the next semester even integral calculus subject is the a prerequisite subject to join some other subjects, such as advanced calculus, mathematical statistics, ordinary differencial equations, and parcial differencial equations. Besides, integral material is learnt for one semester at senior high school. Therefore, it is very important to master this subject especially for future mathematics teachers that are learning in mathematics education. The facts make the material crucial to teach to students in mathematics education.

Integral material is partly taught in natural science program at senior high school. The students from this program have better understanding than those from social science program or vocational school. Meanwhile, most of mathematics students at Widya Dharma University semester 1 in mathematics education program in the academic year of 2013/2014 come from social program and vocational school. They have less under standing of integral concept since the material was not deeply studied in the senior high school. Only some of them come from natural science program.

The data are supported with the students result test in calculus II subject in the academic year of $2013 / 2014$ that shows $65.7895 \%$ of the students haven't had well understanding on calculus material.This condition encourages calculus integral teacher to do research on it. Besides using students analysis, the reshearcher did interview to the students dealing with their problem in learning integral calculus. Based on the result of interview, the identified problems are 1) students' paradigma, the students think that integral calculus is difficult subject and it is not easy to learn since they have to memorize many equations that they don't know how it can be like that or the meaning beyond the equations; 2) the students find difficulties on how to accomplishe the exercise.They are confused about the steps they should do to meet the answer; 3) The students have less strategy in accomplishing the task. They tend to follow how their teacher does the task without reading any references that may help them to face other type of exercise. Therefore, they can't solve other exercise variety; 4) Learning process focuses on teacher, the students tend to be passive. They learn from what the teacher says. They don't have enough chance to share idea in learning process. As the consequence, they can't gain deep understanding toward the material because they don't directly involve in the process. They tend to be listeners.

Therefore, a learning model that can enhance students' motivation and activeness in learning integral subject is highly needed. Active learning is a solution for attractive dan active students' learning activity. Active learning is a learning model that actively involves students in learning process (Silberman, 1996). Students actively participate in learning process by trying and practicing what they are studying. In this case, teacher' role is creating an atmosphere that optimally develops students' capability by giving them chance to identify and relate concepts based on their learning experience. 
There are many learning methods under active learning that can be implemented to solve the problems. One of them is Guided Discovery Learning. Prince and Felder (2006) say that Guided Discovery Learning is an inductive learning model that is relevant with constructivism theory. Guided Discovery Learning independently lets the students do experiments and draw conclusion, opinion, intuition. This model lets them do trial and error. Teacher' role is facilitator in which he will help the students in learning process when he is needed. The students are encouraged to find out idea, concept, and skill by themselves. The teacher guides them so their learning process will lead them to intended understanding. Later, it will be used to gain understanding about the next new concept. How far the teacher guides the students, it depends on the level of material complexity.

In its learning process, Guided Discovery Learning focuses on instruction between teacher, students and learning material. Based Markaban (2008), the interaction is shown as follows.

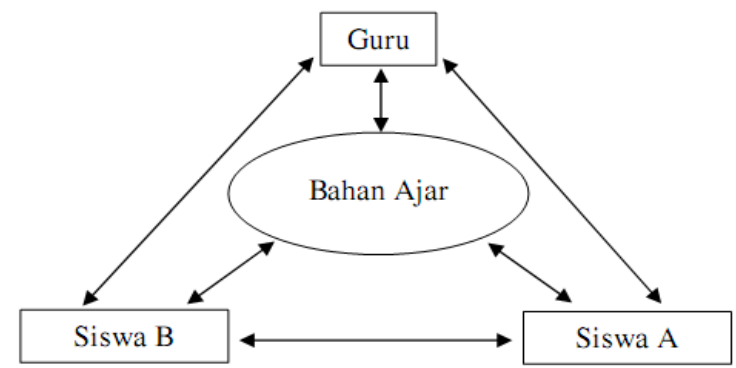

Figure 1. learning activity in Guided Discovery Learning

Interaction happens between teacher to a certain student, some students, or all students in a classroom $(S-G)$, students to students $(S-S)$, students to learning material $(S-B)$, students to learning material to students $(\mathrm{S}-\mathrm{B}-\mathrm{S})$, and students to learning material to teacher $(\mathrm{S}-\mathrm{B}$ $-\mathrm{T})$. The interaction causes the influence each other. Teacher stimulates the students to think by giving some questions that will lead them in understanding and contruction new concepts.

\section{METHOD}

The research was conducted at Mathematics Education, Teacher Training and Education Faculty, Widya Dharma University, Klaten. The research was quasy experimental research because only some of relevant variables that were controlled or manipulated.The sample was the students of Mathematics Education in even semester who took integral calculus subject with the use of certain integral in accomplishing a problem as the material. Cluster random sampling was implemented to find out a representative sample of the population. Based on the result of cluster random sampling, the control group that was taught using Conventional model consisted of 22 students meanwhile the experimental group that was taught using Guided Discovery Learning consisted of 34 students.

The techniques of collecting data were documention, questionnaire, and test. Documentation was implemented to collect data that supported for problem identification in analysis phase. Meanwhile, questionnaire was used to find out students' positive response after joining the learning process and to identify students' perception on learning material; learning reference; and learning method as well. The results of perception questionnaire was used as the basic of hypothesis in the research. The questionnaire consisted of one statement or with two closed 
alternative answers. They were "yes" if the statement was suitable with the reality and "no" if the statement was not suitable. Test was used to measure students' understandimg toward the material.

\section{Angket Respon Positif Mahasiswa}

Petunjuk pengisian angket:

1. Jawablah semua pertanyaan/pernyataan berikut sejujurnya, dengan memberi tanda $\sqrt{ }$ (centang) pada kolom yang sesuai dengan sikap/pendapat tentang perasaan kalian setelah mengikuti pembelajaran Kalkulus Integral

2. Jawaban anda pada angket ini tidak mempengaruhi nilai Anda.

\begin{tabular}{c|c|l|c|c|}
\hline \hline \multirow{2}{*}{ No } & \multicolumn{1}{|c|}{ Pertanyaan/Pernyataan } & \multicolumn{2}{|c|}{ Jawaban } \\
\cline { 2 - 5 } & \multicolumn{1}{|c|}{ Ya } & Tidak \\
\hline 1. & $\begin{array}{l}\text { Menurut Anda, pembelajaran yang telah dilaksanakan } \\
\text { menarik? }\end{array}$ & $\ldots$. & $\ldots$. \\
\hline 2. & $\begin{array}{l}\text { Apakah materi-materi yang dipelajari sudah sesuai dengan } \\
\text { perencanaan? }\end{array}$ & $\ldots$. & $\ldots$. \\
\hline 3. & Apakah pembelajaran mudah dimengerti? & $\ldots$. & $\ldots$. \\
\hline 4. & Apakah Anda termotivasi untuk terus belajar? & $\ldots$. \\
\hline 5. & Apakah pembelajaran mendorong Anda untuk bekerjasama & &
\end{tabular}

Figure 2. The Instrument of Student's Response Questionnaire

The test was given to experimental and control group. The test was done twice. Those are pre test and post test. Pre test was used to identify students' capability before treatment in experimental group and control group as well, whether they have homogeneus capability or not. Post test was implemented to find out the effectiveness of the learning method. It was done after treatment. The both test was in essay.

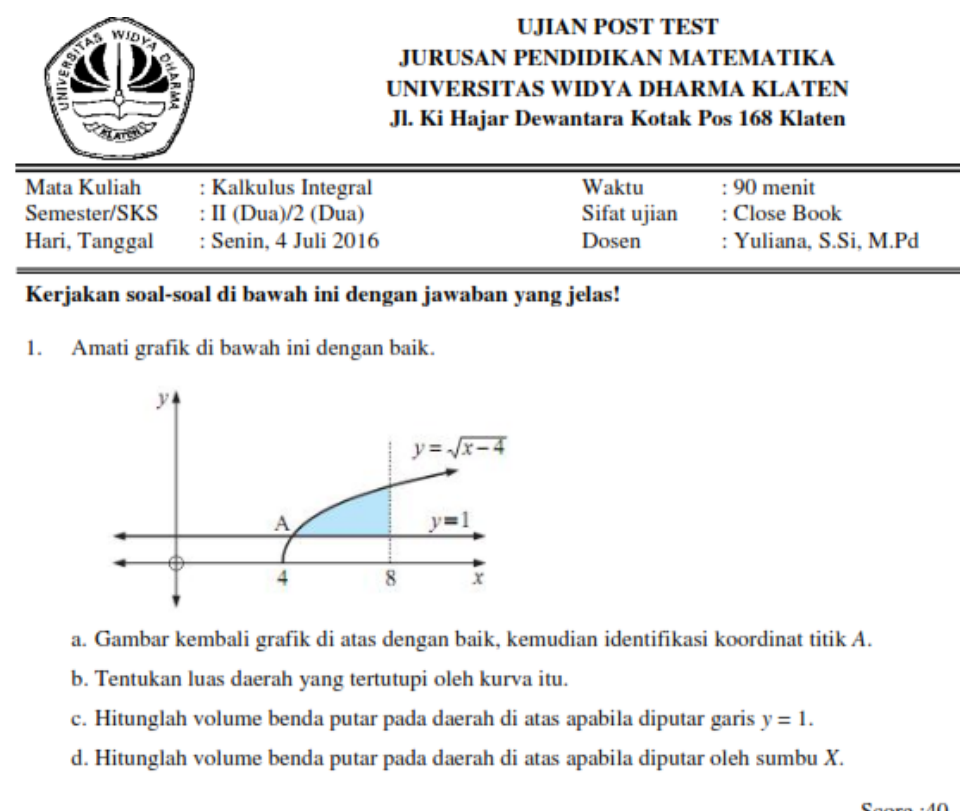

Figure 3. The Instrument of Post-Test Items 
There are two kinds of data in this research. Those are qualitative and quantitative data. Qualitative data covers validation sheet of learning instruments such as lesson plan, learning material, and student response questionnaire. Meanwhile, quantitative data was the students' score in pre test and post test as well. Moleong (2006), says that data analyzing must be started by learning all data from any resources. Data resources of this research were validation sheet, student response questionnaire, and test result.

The quantitative data of the research are pre test and post test score. Pre test score was used for preliminary research while post test was used to identify the effectiveness of learning model. Pre test was used to determine whether the samples were homogeneus or not. This treatment was done to ensure that it was the research which influenced the students' progress. Quantitative data analysis was done twice using t-test for two independent samples : experimental group and control group. The first analysis was done for prerequisite research while the second was used to find out the effectiveness of Guided Discovery Learning. T-test was conducted after normality and homogeneity test had been completed. Normality test was carried out to identify whether the samples came from normal distribution population or not. Normality test used Liliefors method (Budiyono, 2009). Homogeneity test was done to find out whether the population has the same variance or not. Homogeneity test implemented Bartlett method with Chi-square as the statistics test.

Balancing test was done to identify that the group coming from Guided Discovery Learning and group coming from Conventional Model have balanced average. The pre test score was the result of mid term test of even semester. Post test score was taken from the result of students' test after having treatment. Statistical test used for these two scores analysis was ttest.

\section{RESULTS AND DISCUSSION}

\section{Results}

This research developed Guided Discovery Learning Model. The implementation of this model covers in lesson plan, learning material by the researcher, pre test instrument, post test instrument, and questionnaire.

Experimental and control group have the same duration in learning. Each of them has 8 meetings. Before conducting the research, the two groups had been ensured that they had similar condition. It was measured through pre test that was analyzed using t-test. After that, they got treatment. Experimental group was taught through Guided Discovery Learning while control group was taught using Conventional Model. Post test was conducted after all groups had got treatment. The result of post test then was analyzed using t-test which then the effectiveness learning model could be identified. 


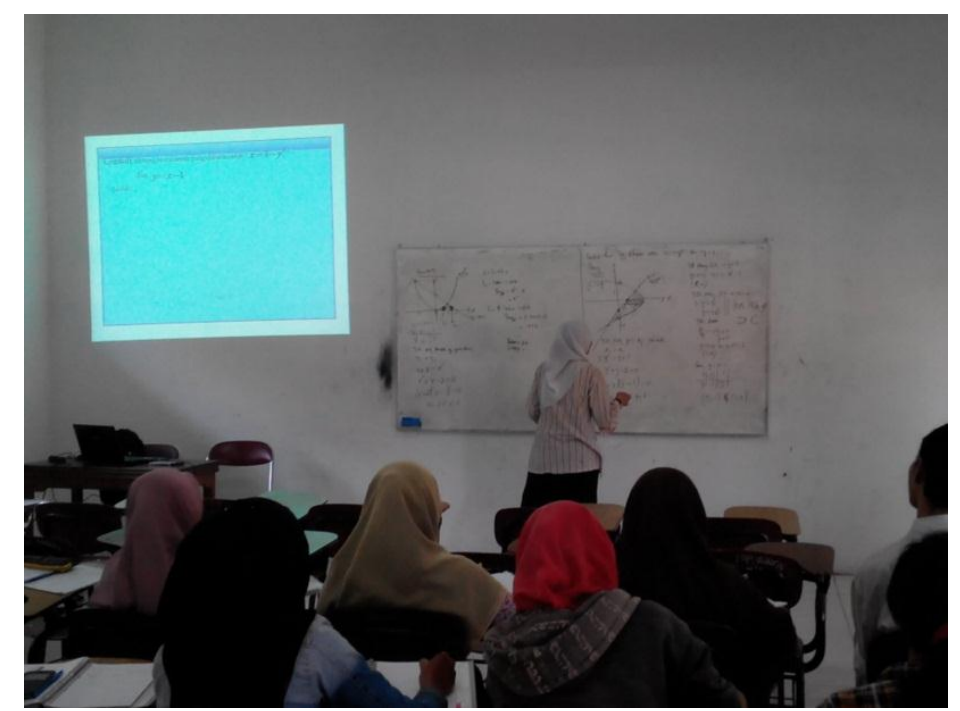

Figure 4. Students' Learning Activity in Guided Discovery Learning.

Learning instrument that was developed by the researcher was learning material for integral calculus. The instrument was validated by using expert judgement method. There were 3 validators in this research. The validators were trusted and qualified validators. They were the masters on their field, mathematics education, and had experience in research. The validation covered learning material, lesson plan, pre test items, post items, and positive respond questionnaire.

The learning material of the research was matched with the regular material that should be learnt by the students on that semester. This research was in line with Rosita (2016) that says teacher should provide and develop learning material that is suitable with the student's characteristic and social environment. The material that was developed in this research was adapted with the characteristic of integral calculus material and the learning model that was developed. Validation test was applied toward learning material to ensure that it was in line with its objective. Based on the result of validation the learning material has already had all indicators as a ready learning material to use for integral calculus in experimental group.

The pre test items and post test items had already been validated by the validators. The pre test items were 3 essays about indefinite integral and integral technique. Meanwhile, the post test items were 3 essays about the implementation of definite integral to answer a matter about the area and volume of spinning object. Those both test items were regarded as valid item test by the validators.

Lesson plan consisted of eight meetings. Lesson plan needed to be validated the learning objectives, standard competency, and learning step. The validators stated that the lesson plas was valid. Therefore, the lesson plan was ready to use in experimental class.

Questionnaire that was used in this research was positive response questionnaire.The questionnaire consisted of 16 statement items, with yes or no response. Before the questionnaire was used, it had been stated as a valid questionnaire by the validators. So, the questionnaire was ready to use in this research.

The pre test was carried out on Friday, May $5^{\text {th }}$ 2016. The pre test result can be seen as follows on Table 1. 
Table 1. The Students' Pre Test Result

\begin{tabular}{lcc}
\hline & $\begin{array}{c}\text { Experiment } \\
\text { Group }\end{array}$ & Control Group \\
\hline The number of students & 34 students & 22 students \\
The highest score & 30 & 38 \\
The lowest score & 100 & 82 \\
Mean score & 64.382 & 55.591 \\
Standard deviation & 17.861 & 12.89 \\
\hline
\end{tabular}

The data above on table 1 then was analyzed using normality test and homegeneity test as prerequisite test before $t$ test. The result of normality test is shown on the Table 2 .

Table 2. The Normality Test Result of Pre test

\begin{tabular}{llrcl}
\hline \multicolumn{1}{c}{ Group } & \multicolumn{1}{c}{$\mathbf{L}_{\text {obs }}$} & DK & Decision & Conclusion \\
\hline Experiment & 0.10271 & 0.151948 & $\mathrm{H}_{0}$ is accepted & Normal \\
Control & 0.167764 & 0.190000 & $\mathrm{H}_{0}$ is accepted & Normal \\
\hline
\end{tabular}

Based on the result of normality test, samples in experimental and control group are in normal distribution. The second prerequisite test was homogenity test. Bartlett method was used in variance homogenity test. The result was $\chi_{\mathrm{obs}}^{2}=2.5140 \notin \mathrm{DK}$ with $\chi_{(0.05 ; 1)}^{2}=3.84145915$. The result described that $\mathrm{H}_{0}$ is accepted, it means the both variances are homogeneus. Having tested its normality and homogeneity, the next test was t test. T-test was conducted to ensure that both groups, experimental and control had similar condition. The result of T-test was $\mathrm{t}=1.9942562 \notin \mathrm{DK}$, with $\mathrm{DK}=\{\mathrm{t} \mid \mathrm{t}<-2.306$ or $\mathrm{t}>2.306\}$. So, $\mathrm{H}_{0}$ is accepted. It means the students in experimental and control group have similar capability.

Post test was carried out after both groups had treatment. The post test was done on Monday, July $4^{\text {th }} 2016$. The result of post test is described on the Table 3 as follows.

Table 3. The Result of Post Test

\begin{tabular}{lcc}
\hline & $\begin{array}{c}\text { Experiment } \\
\text { Group }\end{array}$ & Control Group \\
\hline The number of students & 34 students & 22 students \\
The highest score & 30 & 22 \\
The lowest score & 75 & 65 \\
Mean score & 60.5 & 46.455 \\
Standard deviation & 8.302 & 11.673 \\
\hline
\end{tabular}

The data then was analyzed through normality and homogeneity test as the prerequisite test before $t$ test. Lilifoers test was done to know the normality of the data. The normality test can be seen on Table 4 as follows. 
Table 4. The Result of Normality Test in Post Test

\begin{tabular}{lrrrl}
\hline \multicolumn{1}{c}{ Group } & $\mathbf{L}_{\text {obs }}$ & DK & Decision & Conclusion \\
\hline Experiment & 0.146792 & 0.151948 & $\mathrm{H}_{0}$ is accepted & Normal \\
Control & 0.12122 & 0.190000 & $\mathrm{H}_{0}$ is accepted & Normal \\
\hline
\end{tabular}

The data shows that the samples in both experimental and control group are in normal distribution. The second prerequsuite test is variance homogenity test. Bartlett method was implemented in the test. The result was $\chi_{\mathrm{obs}}^{2}=3.01771123 \notin \mathrm{DK}$ with $\chi_{(0.05 ; 1)}^{2}=3.84145915$. Based on the test, $\mathrm{H}_{0}$ is accepted. It means the variance of the samples in both groups are homogeneus.

After all prerequisites test had been fullfiled, the next step is identifying the effectiveness of the learning model for each group. $T$ test was done to find out the conclusion. $T$ test result was $t=5.26355152 \in \mathrm{DK}$, with $\mathrm{DK}=\{\mathrm{t} \mid \mathrm{t}>2.0049\}$. The decision could be drawn was that $\mathrm{H}_{0}$ was accepted. The average of post test in experimental group is better than that in control group. So, it can be concluded that Guided Discovery Learning Model is more effective than Conventional Model to teach integral calculus.

Questionnaire was distributed to the students after they had learning process through Guided Discovery Learning. The students' response toward learning process was identified through the result of questionnaire. The result of questionnaire that was given to 34 students was the item of the questionnaire at least got $52.94 \%$ positive response. More than $75 \%$ questionnaire items got $67.65 \%$ positive response. It means Guided Discovery Learning can increase students' interest in joining integral calculus class. The increase of students' interest can improve the students' understanding toward integral calculus material.

\section{Discussion}

Based on the result of data analysis, the conclusion was appropriate with the writer's hypothesis. It is Guided Discovery Learning Model is more effective than Conventional Model to improve students' understanding toward integral. Guided Discovery Learning Model was proven more effective because in its learning process students were involved in finding the concept. Therefore, the students got unforgatable and meaningful learning experience that helped them to understand the material in which there were many equations to understand and remember. The role of teacher was as facilitator. He guided the students to find out the concept that they should understand. The result of this research was in line with Dumitrascu (2009). It was stated that Guided Discovery Learning Model is a learning model that is able to improve students' understanding of a concept.

In Guided Discovery Learning class, modification was done by grouping the students into some group discussions. This technique was the same with what the researcher had done in 2011, Yuliana (2011). This learning step of Guided Discovery Learning attracted the enthusiasm of the students in joining the class. The students' interest can be seen in the result of positive response questionnaire. Moreover, the finding of this research was supported by the result of Cohen's research (2008). The result was Guided Discovery Learning was a more enjoyable and effective learning model than direct Learning. He concluded that the students taught by using Direct Learning is faster in fulfilling the test, but they missed some important 
points of tests. Therefore, Guided Discovery Learning was more recommended. The results support the reseacher's finding that states Guided Discovery Learning is effective to improve students' concept of integral calculus subject.

\section{CONCLUSION}

Based on the result of data analysis, the conclusions are: (1) learning process in experimental group was in line with the lesson plan. The result of validation is regarded as a very valid category. (2) The students' achievement on integral calculus subject who are taught using Guided Discovery Learning is better than those who are taught using Convention Model. It can be identified from the result of post test. The result of $t$ test was $t=5.26355152 \in \mathrm{DK}$, with $D K=\{t \mid t>2.0049\}$. It shows that the average score of the students coming from experimental group was better than those coming from control group. It means Guided Discovery Learning is better than Conventional Model to teach integral calculus material. Moreover, the suggestions that can be drawn are: (1) Mathematics teacher is suggested to implement Guided Discovery Learning to teach integral for the students. (2) Researcher is suggested to apply other active learning model that is able to develop students' ability and motivate them in learning mathematics.

\section{ACKNOWLEDGMENTS}

The researcher expresses his deep gratitude to Widya Dharma University that has given permission and support to conduct this research. Besides, thank you very much for DIKTI (the ministry of high education) that has given financial support so the research can be well accomplished.

\section{REFERENCES}

Budiyono (2009). Statistik untuk Penelitian (Edisi 2). Surakarta: UNS Press.

Cohen, M.T. (2008). The Effect of Direct Instructions Versus Discovery Learning on the Understanding of Science Lessons by Second Grade Students. Journal of Northeastern Educational Research Association (NERA), 30, 1-28.

Dumitrascu, D. (2009). Integration of Guided Discovery in the Teaching of Real Analysis. Journal of Educational Studies in Mathematics. 19(4).370-380.

Markaban (2008). Model Penemuan Terbimbing pada Pembelajaran Matematika SMK. Paket Fasilitasi Pemberdayaan KKG/MGMP Matematika. Yogyakarta: P4TK Matematika.

Moleong, L. J. (2006). Metodologi Penelitian Kualitatif. Bandung: PT. Remaja Rosdakarya.

Prince, M.J \& Felder, R.M. (2006). Inductive Teaching and Learning Methods: Definitions, Comparisons, and Research Bases. Journal of Engineering Education, 95 (2), 123138.

Rosita, C.D. (2016). The Development of Courseware Based on Mathematical Representations and Arguments in Number Theory Courses. Infinity, 5 (2), 131-140.

Silberman, M.L.(1996). Active Learning 101 Strategies to Teach Any Subject. USA: Allyn and Bacon. 
10 Yuliana, Tasari \& Wijayanti, The Effectiveness of Guided Discovery Learning ...

Yuliana.(2011). Eksperimentasi Pembelajaran Matematika dengan Model Kooperatif Tipe Student Team Achievement Divisions (STAD) dan Penemuan Terbimbing Ditinjau Dari Aktivitas Belajar Siswa pada Pokok Bahasan Persamaan Garis Lurus Kelas VIII Di SMP Negeri Se-Kabupaten Klaten Tahun Ajaran 2011/2012. In Budiyono, Mardiyana, I. Sujadi, \& Sutopo (Eds). Seminar Nasional dan Pendidikan Matematika (153-162). Surakarta : Pelangi Press. 